O.E.E.S., Code de la libération. Parijs, augustus 1959. 217 blz.

Deze nieuwe editie van de Code is bijgewerkt tot 1 augustus 1959; de Franse en Engelse tekst staan naast elkaar afgedrukt.

O.E.E.S., Economic Conditions in Member and Associated Countries of the OEEC; Canada. Parijs, 1959. 31 blz.

Idem; United States. Parijs, 1959. 41 blz.

Economisch Instituut voor de Middenstand, Enkele ontwikkelingslijnen in Detailhandel en Ambacht 1953-1958. Den Haag 1959. 44 blz.

Het rapport onderzoekt de oorzaken van de teruggang van het aantal vestigingen en de aanmerkelijke verbetering van de inkomenspositie in ambacht en detailhandel.

\title{
UIT DE ECONOMIST VAN 1859
}

Op 31 December van dit jaar zal de vierde algemeene tienjarige volkstelling in het Koningrijk der Nederlanden plaats hebben. Bij koninklijk besluit van 26 September jl. (Staatsblad no. 101) zijn de voorschriften daaromtrent gegeven, en is een billet vastgesteld, hetwelk, naar de bepaling van art. 4, aan de hoofden der huisgezinnen ter invulling zal worden ter hand gesteld.

Wij hadden wel gewenscht dat, als regel, die invulling aan ambtenaren ware opgedragen geworden. Wij zien daarin meerderen waarborg voor eenen gewenschten uitslag, maar nu de invulling door de ingezetenen zelve eenmaal is voorgeschreven, is de gedachtenwisseling daaromtrent voor het oogenblik overbodig. $\mathrm{Er}$ bestaat thans eene andere roeping, het is die om de goede gezindheid der bevolking tot invulling zoo veel mogelijk te bevorderen. (...)

Wanneer de regering, in plaats van een aantal ambtenaren met pen en inkt in de woningen te zenden, de hoofden der huisgezinnen tot het doen der verlangde opgaven roept, dan legt zij daardoor de veronder. stelling aan den dag dat die hoofden het nut van het werk gereedelijk zullen erkennen. Men mogt dit dan ook verwachten in een land als het onze, waar de ingezetenen door vrijheid van denken en spreken, openbaarheid van regerings-daden en het bezit van een aantal gezonde geschriften over staat- en staathuishoudkunde, gelegenheid hebben gehad hunne begrippen omtrent het maatschappelijk leven en zijne eischen te zuiveren, maar de ondervinding leert hoeveel bekrompenheid ook op dat gebied nog bij de burgers van den staat gevonden wordt.

W. T. Sandberg, Onze aanstaande volkstelling (blz. 409). 